\title{
Do GDP and Energy Consumption Increase CO2 Emissions? An Analysis of Brazil, India and China
}

\author{
Indira Mara Santos \\ School of Economics, Huazhong University of Science and Technology \\ 1037 Luoyu Road, Wuhan, Hubei, China 430074
}

\begin{abstract}
This study analyses the short and long run impact of trade, energy consumption and CO2 emissions on economic growth in Brazil, India and China. The time series considered is from the period of 1978-2014. By employing ARDL bound testing approach, the long and short run effects are estimated. With Error Correction model, the findings provide that there is a short run relationship between energy and export, leading to $\mathrm{CO} 2$ emissions in China, there is no significant relationship between the variables and $\mathrm{CO} 2$ emissions in India and a short run relationship between $\mathrm{CO} 2$ emission and energy consumption in Brazil. The study implies that policy makers in China need to give special attention for energy sector and non-convertible energy in export sector for reduction in $\mathrm{CO} 2$ emissions. In India, it is essential to consider other factors that are responsible for $\mathrm{CO} 2$ emissions in the country. And in Brazil, the results suggest an inefficiency of the use of energy and that export oriented industries in Brazil have been diverted to convertible or renewable energy sources.
\end{abstract}

DOI: $10.7176 / \mathrm{JETP} / 9-7-03$

Publication date:October $31^{\text {st }} 2019$

\section{Introduction}

With the advent of industrial revolution almost a century ago, the growth of countries has significantly increased the income per capita of its populations. Achieving high economic growth and continuous development has remained a primary objective of the countries for the wellbeing of their inhabitants. Today, many advanced and developed countries have been successful in achieving high economic growth and continuous development that has also laid the footprints to follow for other developing countries.

As a major factor of growth and development, the energy has been considered as a source of production of goods and services, intensifies labour and capital. According to IEA (2018a), energy intensity improved by $1.3 \%$ between 2017 and 2018 worldwide. IEA (2018j) also shows that European Union had an electricity consumption of 2.464.62 TWh in 1990 and 3.071.34 TWh in 2016, an increase of 25\%. United States had a consumption of 2.923.92 TWh in 1990 and 4.147.5 TWh in 2016, increasing by 42\% (IEA, 2018k). The increase can be even more relevant in developing countries. In Brazil, the electricity consumption was $217.66 \mathrm{TWh}$ in 1990 and increased to $579.02 \mathrm{TWh}$ in 2016 (IEA, 2018i). A growth of 139\%. India had a consumption of $237.59 \mathrm{TWh}$ in 1990 and in 2016 it reached 1.216.11 TWh (IEA, 2018g), an escalation of $412 \%$. But even more impressive are China numbers. In 1990, its consumption was of 579.65 TWh. By 2016, it has increased to 5.898.89 TWh (IEA, 2018h), representing an evolution of $918 \%$. The electricity consumption growth can be reflected on the development of these countries in economy and in life quality for its inhabitants as well.

Many empirical studies have signified the importance of energy in growth and development. Chen et al. (2016) studied the relationship of economic growth, energy consumption, and greenhouse gas emissions in 188 countries and concluded a long-run relationship economic growth, energy consumption and carbon dioxide emissions for all countries. Yoo and Kwak (2010) analyzed the relation between economic growth and energy consumption in Latin American countries and concluded a positive relationship and Granger causation between them. Narayan and Smyth (2009) studied the relationship between energy consumption, exports and GDP in Middle Eastern countries and also concluded on positive relationship and bidirectional causation between energy and growth, In case of energy deficiency, the economic and social development of the country is highly affected. Talib and Fan (2019) studied the relationship between energy consumption, manufacturing output and economic growth and the results provide the unidirectional causal relationship between manufacturing output and economic growth, indicating that Pakistan needs to enhance the capacity of the energy sector for the efficacy of the manufacturing productivity leading to economic growth. Santos and Zhaohua (2019) analyzed the relationship between energy consumption, capital formation and trade on economic growth, exhibiting a weak but bidirectional causality between gross capital formation and economic growth whereas, gross capital formation and economic growth are unidirectional granger causing energy consumption respectively, implying that policy makers need to increase the efficacy of energy sector promoting economic growth.

Parallel to the economic development, the use of energy is also regarded as one of the most significant green house gas $(\mathrm{GHG})$ emitter and also regarded as an underlying cause of global warming. The estimates provided by the Energy Information Agency indicate that the increasing population and growth will significantly increase the energy demand with a share of energy consumption in developing countries increasing from 51\% in 2004 to $58 \%$ 
in 2040 (EIA, 2007). With emphasis on the fossil fuels and non-renewable energy resources specially oil, gas and coal, the increase in production will lead to deforestation (Wang et al., 2016) and high GHG emissions (EPA, 2018).

Danish et al (2018) argues that the high GHG emission of developing countries is a phenomenon related to the industrial development combined with population growth. The economic growth is the main goal of developing countries that endeavor to increase their production and life quality for its inhabitants and it can be defined as the structural transformation where manufacturing shifts from low to high quality and increase its production capacity (Dinç and Gokmen, 2019) and GDP is the instrument that helps to indicate the strength and the living standards of an economy. If we consider the case of developed countries with consistent high economic growth, the development can be reflected by the $\mathrm{CO} 2$ emission numbers in the past, implying that GHG emissions are directly linked with economic growth. By following the same strategy of economic growth, developing countries have also brought the adverse effects of $\mathrm{CO} 2$ emissions. Among the developing countries, Brazil, China and India are found to be as large GHG emitters as the developed nations. China CO2 emission by GDP in 2016 was about $0.95 \mathrm{~kg}$, followed by India with $0.84 \mathrm{~kg}$ and Brazil with $0.19 \mathrm{~kg}$ (IEA, 2018b,c,d). While in European Union (EU), the emission of CO2 by GDP in 1990 was of $0.34 \mathrm{~kg}$ and has reduced to $0.17 \mathrm{~kg}$ in 2016 . In United States (US), the CO2 emission by GDP in 1990 was of $0.53 \mathrm{~kg}$ and it has reduced to $0.29 \mathrm{~kg}$ in 2016 (IEA, 2018e,f). These numbers reveals not only the high demand of energy, but also the lack of clean energy technologies and the inefficiency of energy use and pollutants controls in developing countries (Chen et al, 2016).

China, the fastest growing economy in the world, represents approximately $22 \%$ of the global energy consumption (Khobai, 2018) and the sum of industrialized regions in the country with the developed countries accounts two-thirds of GHG emission globally (Chen et al, 2016). Besides its heavy industrialization, urbanization has also been a vital pointer of economic growth for Chinese society, with a projection from UNDP to increase to $70 \%$ by 2030 (Rauf et al, 2018), but this has also impacted on the unpleasant environmental quality. The CO2 emissions in China have turned out to be one of the most popular subjects that involve national and overseas investigators for this critical challenge: to drop the CO2 emission or make it low carbon economy (Rauf et al, 2018). Since most of the country's energy mix is based on carbon intensive industries (Wang et al., 2016), the biggest challenge for contemporary China is to control fossil-energy consumption while continuing to pursue economic growth. For that, there is a necessity for optimize the industrial structure, to improve energy efficiency, to increase the share of green energy and energy conservation in order to reduce $\mathrm{CO} 2$ emissions while also continue to grow and develop (Wang et al., 2016).

Brazil, as an important Latin American and developing country, also struggles with increasing the economic growth while having the responsibility to protect the environment, especially hosting the Amazon ecological area, which holds the most biodiverse area in the world and it's responsible for $20 \%$ of world's oxygen production. In its energy mix, Brazil constitutes 57\% of fossil fuels (Enerdata, 2014) and according to the 2009 EIA, Brazil's renewable electricity generation reached $97 \%$ of its total and even though the growth rate of different types of energy consumption varies, it is one of the world's cleanest matrices (Pao and Fu, 2013). Shahbaz et al (2014) believes that the presence of substitutability in energy consumption will provide an avenue for the continued use of government policies that enhance the development of the sector as well as encourage the effective development of carbon markets in Brazil to reduce fossil fuel use and also believes that there should be more policies related to tax incentives, sales tax, and green certificate trading, to promote the development of a clean energy economy. Despite some relevant and impressive aspects as: the expressive economic power that have illustrated its acceleration in some developing and industrialized countries (Amri, 2019) and its energy industry is the second largest in the country, right after mining (Seplan, 2018) and energy production frequently being a reflection of the productivity capacity or life quality of its population, the country faces severe challenges to bring more equality to the society and a more sustained development to the economy.

Similarly, India is a developing country that has emerged as an important regional power that is also challenged with social, economic and environmental problems, while also being a rising economic powerhouse. Due to its high population growth and rapid rise in industrial output, India is predicted to become the fastest growing energy consuming country by 2035 and to reach $9 \%$ share of the world's total energy consumption (Eren et al., 2019). According to EIA (2016), in 2013, India was the third-largest energy consumer in the world after China and the United States, and despite having notable fossil fuel resources, the country has become increasingly dependent on energy imports. The country's largest energy source is coal (44\%), followed by traditional biomass and waste $(24 \%)$ and petroleum and other liquids (23\%) (EIA, 2016). The renewable energy in India is composed of hydroelectricity, non-hydroelectric renewables, solar, tide, wave, fuel cell, wind and, biomass and waste (Eren et al., 2019). Although the capacity potential is significant, so far it make up a small portion of primary energy consumption (EIA, 2016). One of the challenges of the country is to deliver essential access to electricity, since $19 \%$ of the population doesn't have access and the energized zones still face problems of power outages (EIA, 2016).

Those three countries are part of BRICS, a cooperative bloc composed by Brazil, Russia, India, China and 
South Africa, that have the potential to generate concrete results for member countries in areas as economy, health, science and technology. Together, the group represents about $42 \%$ of world's population, $23 \%$ of world's GDP, $30 \%$ of world's territory and 18\% of world's trade (MRE, 2019). In terms of energy, the BRICS countries accounted for $37 \%$ of the world energy demand in 2015 and for $41.4 \%$ of the $\mathrm{CO} 2$ emissions due to energy usage, because of the great presence of mineral coal in its energy matrix (SPE, 2016). The Domestic Energy Supply on the BRICS (energy required to boost countries' economies) reached $37 \%$ of the word energy. Coal is the most significant share of the 2014 BRICS's energy matrix (51.1\%), followed by Oil (20\%) and Natural Gas (12.3\%), with a total of $83.4 \%$ of fossil sources. Renewables sources represent $13.8 \%$ of the worldwide matrix. Brazil is responsible by $5.9 \%$ of the BRICS's total energy consumption, while China, by $60.8 \%$ and India, $16.7 \%$ (SPE, 2016). Therefore, the analysis of these countries performance in energy and growth is extremely relevant.

This paper aims to add to the literature of endogenous-growth hypothesis, emphasizing on the short and long run relationship between energy consumption, trade and economic growth in Brazil, India and China. It also aims to fill the gap of studies where it analyses the three most promising developing economies. For this study it will be used the ARDL bound testing approach and the evidence of the direction of causality among the variables will be provided by using Granger Causality analysis.

The ARDL technique by Pesaran et al. (2001) has points of interest over different estimators. Since it doesn't require testing for unit roots, it can show which variable ought to be the reliant variable and it computes both short and long run estimates through linear transformation technique and its suitable in case of mixed stationarity at I (0) and I (1). Engle and Granger (1987) coordinated the idea of cointegration into causality, expressing that causal relations among factors can be inspected inside the structure of the ECM. A period arrangement (X) is said to Granger-cause some other time arrangement (Y) if the forecast mistake of current $\mathrm{Y}$ decays by utilizing past estimations of $\mathrm{X}$ notwithstanding past estimations of $\mathrm{Y}$, the blunder amendment term contains the data of long run causality. Henceforth, significance of each explanatory variable lags depict short run causality. Then again, a negative and statistical noteworthy error adjustment term is accepted to mean long run causality.

The paper follow this structure: section one is the introduction, followed by section two with data description, section three provides the methodology, section four brings the results and analysis and section 5 presents the conclusion of this work.

\section{Data Description}

The variables for this study have been taken from World Development Indicators (WDI), from the available period of 1978-2014 for Brazil, China and India. It was considered as variables Exports, Energy Use and CO2 emission.

\section{Methodology}

Following Pesaran et al. (2001), this study relies on the ARDL bound testing method for calculating both short and long run estimates through linear transformation technique and more suitable in case of mixed stationarity at I(0) and I(1), the relationship between total energy consumption, economic growth, exports and capital is modeled as follows:

$$
\Delta C O 2_{t}=\alpha_{0}+\sum_{i=1}^{f} \omega_{i} \Delta E N_{t-i}+\sum_{i=0}^{g} \delta_{i} \Delta E X P_{t-i}+\gamma_{1} C O 2_{t-1}+\gamma_{2} E N_{t-1}+\gamma_{3} E X P_{t-1}+\mu_{t}
$$

Where $\Delta$ is the first difference operator; $\omega$ and $\delta$ are the coefficients for EN and EXP; $u_{t}$ is the error term; and $f$ and $g$ are the lag length selected by Akaike Information Criteria (AIC). Later, it has been conducted Durbin Watson (DW) and LM test for autocorrelation and white test for heteroskedasticity. As the next step, it was conducted Durbin Watson (DW) and LM test for autocorrelation and white test for heteroskedasticity. To find the direction of causality, the Granger Causality was applied considering the framework of VECM:

$$
\Delta C O 2_{t}=\alpha_{0}+\sum_{i=1}^{q} \partial_{i} \Delta E N_{t-i}+\sum_{i=0}^{r} \emptyset_{i} \Delta E X P_{t-i}+\rho_{3} E C M_{t-1}+\varepsilon_{2 t}
$$

Where $\Delta$ is the first difference operator; $\partial$ and $\emptyset$ are the coefficients EN and EXP; $u_{t}$ is the error term; and $q$ and $r$ are the lag length selected by Akaike Information Criteria (AIC). $E C M_{t-1}$ is the error correction term in consideration of long-run relationship. Whereas, $\varepsilon_{2 t}$ its coefficient is the speed adjustment to the long run equilibrium.

\section{Results}

\subsection{Bound Testing Results}

Table 1 present the results of the cointegration test, with values for upper and lower bound taken from Pesaran et al. (2001). The F statistics were estimated with Bound Testing Approach. For optimal lag selection, it has been selected lag length 1 while taking VAR lag selection of Akaike information criteria (AIC). The confirmation of cointegration among variables is confirmed, as the value of F statistic lie above than 5.61. 
Table 1: Bound test for Cointegration

\begin{tabular}{llll} 
& China & India & Brazil \\
\hline Test Statistics & Values & Value & Value \\
\hline F-Statistics & 12.958 & 11.956 & 11.992 \\
CV Bounds & & & \\
& Significance & $\mathrm{I}(0)$ Bound & $\mathrm{I}(1)$ Bound \\
& $10 \%$ & 2.72 & 3.77 \\
& $5 \%$ & 3.23 & 4.35 \\
& $2.50 \%$ & 3.69 & 4.89 \\
& $1 \%$ & 4.29 & 5.61 \\
\hline
\end{tabular}

\subsection{ARDL Long Run and Short Run dynamics}

As analyzed in the estimations, China being a fastest growing export-led industrialized economy has been found significant with energy consumption as well as exports in long run. Whereas, in short run the analysis also shows that the positive relationship exists between energy consumption as well as exports with $\mathrm{CO} 2$. The short run estimates also provide the similar results exhibiting both variables responsible for increase in $\mathrm{CO} 2$ emissions. By considering granger causality it can be seen that bidirectional causality has been found between energy usage and $\mathrm{CO} 2$ emissions whereas unidirectional causality has been found where exports are also unidirectionally causing energy usage. It implies that energy sector of China is important to consider. It is important to limit the use of nonconvertible energy in export sector for reduction in $\mathrm{CO} 2$ emissions.

By examining the estimates of India it can be seen that none of the sectors are responsible for the $\mathrm{CO} 2$ emissions yet a weak short run positive relationship has been found between energy consumption and $\mathrm{CO} 2$ emissions. Whereas, Granger causality analysis provides none of the variables are Granger causing each other. It is important to consider other factors that are responsible for $\mathrm{CO} 2$ emissions in India.

While considering Brazil, being an important country in Latin America and developing country, the dynamics of $\mathrm{CO} 2$ emissions stand different. It can further be seen that a short run positive relationship has been found between $\mathrm{CO} 2$ emissions and energy use whereas, exports has established a short as well as long run negative relationship with $\mathrm{CO} 2$ which confirms that much of the export oriented industries in Brazil have been diverted to convertible or renewable energy sources. Though, it is an established fact that the deindustrialization effect has limited the exports in the Latin American countries but in Brazil the exports has also been found related with renewable energy which provides that increase in exports will decrease the $\mathrm{CO} 2$ emissions. In geography perspective, it is important for Brazil to rely on renewable energy sources, because of Amazon. Any increase in $\mathrm{CO} 2$ emissions in Brazil may affect the ecology of the country in particular and of the region in general. Whereas, Granger causality also supports the bidirectional causality between $\mathrm{CO} 2$ emissions and exports in the country and energy consumption granger causes exports unidirectionally.

By considering three important countries of BRICS, it is important to make comparison of three economies to understand the dynamics of $\mathrm{CO} 2$ emissions. It has been found that China being an export led industrial country is having $\mathrm{CO} 2$ emissions through export and energy consumption whereas in Brazil's exports has limited negative relationship with $\mathrm{CO} 2$ emissions. 


\begin{tabular}{|c|c|c|c|}
\hline $\begin{array}{l}\text { Country } \\
\text { Lag selection(AIC) }\end{array}$ & $\begin{array}{l}\text { China } \\
(2,1,0)\end{array}$ & $\begin{array}{l}\text { India } \\
(1,1,0)\end{array}$ & $\begin{array}{l}\text { Brazil } \\
(1,1,1)\end{array}$ \\
\hline \multicolumn{4}{|l|}{ Short Run Analysis } \\
\hline $\mathrm{CO} 2(\mathrm{t}-1)$ & $\begin{array}{l}0.317 \\
(0.1654)\end{array}$ & $\begin{array}{l}0.0150 \\
(0.1787)\end{array}$ & $\begin{array}{l}0.298^{*} \\
(0.1419)\end{array}$ \\
\hline $\mathrm{CO} 2(\mathrm{t}-2)$ & $\begin{array}{l}-0.310^{*} \\
(0.1228)\end{array}$ & & \\
\hline Energy Use & $\begin{array}{l}0.459 * * \\
(0.1305)\end{array}$ & $\begin{array}{l}0.764 * \\
(0.3627)\end{array}$ & $\begin{array}{l}0.395^{*} \\
(0.1598)\end{array}$ \\
\hline Energy Use(t-1) & $\begin{array}{l}0.307 \\
(0.1627)\end{array}$ & $\begin{array}{l}-0.627 \\
(0.3917)\end{array}$ & $\begin{array}{l}-0.338 \\
(0.1712)\end{array}$ \\
\hline Exports & $\begin{array}{l}0.0574^{\wedge} \\
(0.0286)\end{array}$ & $\begin{array}{l}0.00439 \\
(0.0736)\end{array}$ & $\begin{array}{l}-0.0388 \\
(0.0302)\end{array}$ \\
\hline Exports $(\mathrm{t}-1)$ & & & $\begin{array}{l}-0.0799 * \\
(0.0303)\end{array}$ \\
\hline Error Term(t-1) & $\begin{array}{l}-0.993 * * * \\
(0.1632)\end{array}$ & $\begin{array}{l}-0.98 * * * \\
(0.1787)\end{array}$ & $\begin{array}{l}-0.70 * * * \\
(0.1419)\end{array}$ \\
\hline \multicolumn{4}{|l|}{ Long Run Analysis } \\
\hline Energy Use & $\begin{array}{l}0.771 * * * \\
(0.1134)\end{array}$ & $\begin{array}{l}0.139 \\
(0.4642)\end{array}$ & $\begin{array}{l}0.0809 \\
(0.3257)\end{array}$ \\
\hline Exports & $\begin{array}{l}0.0578^{\wedge} \\
(0.0294)\end{array}$ & $\begin{array}{l}0.00446 \\
(0.0750)\end{array}$ & $\begin{array}{l}-0.169 * \\
(0.0685)\end{array}$ \\
\hline _cons & $\begin{array}{l}-0.0676^{* * *} \\
(0.0122)\end{array}$ & $\begin{array}{l}-0.00288 \\
(0.0115)\end{array}$ & $\begin{array}{l}0.00370 \\
(0.0056)\end{array}$ \\
\hline $\mathrm{N}$ & 37 & 37 & 37 \\
\hline R-sq & 0.6189 & 0.6156 & 0.6449 \\
\hline Diagnostic Tests & Prob & Prob & Prob \\
\hline LM-Statistics(bgodfrey Prob) & 0.9116 & 0.5564 & 0.903 \\
\hline Heteroscedasticity & 0.5936 & 0.0526 & 0.2382 \\
\hline
\end{tabular}

Note: Coefficients are reported with standard errors in brackets. $* * *, * *, *$ indicate significance at 0.001 , $0.01,0.05$, respectively. $\Delta$ defines the first difference. All of the above estimations are based on the error correction model. (t-1) represents first lag. DW statistics and LM statistics test for autocorrelation and Heteroskedasticity is tested with White test.

Table 3: Granger Causality

\begin{tabular}{|ll|lll|lll|lll|}
\cline { 2 - 10 } \multicolumn{1}{c|}{} & \multicolumn{3}{c|}{ China } & \multicolumn{3}{c|}{ India } & \multicolumn{3}{c|}{ Brazil } \\
\hline Equation & Excluded & chi2 & df & Prob>chi2 & chi2 & df & Prob>chi2 & chi2 & df & Prob $>$ chi2 \\
\hline CO2 & Energy & 8.498 & 2 & 0.014 & 2.676 & 2 & 0.262 & 4.392 & 2 & 0.111 \\
CO2 & Exports & 1.266 & 2 & 0.531 & 2.150 & 2 & 0.341 & 8.723 & 2 & 0.013 \\
CO2 & All & 9.211 & 4 & 0.056 & 5.499 & 4 & 0.240 & 15.24 & 4 & 0.004 \\
\hline Energy & CO2 & 7.671 & 2 & 0.022 & 0.0043 & 2 & 0.998 & 0.544 & 2 & 0.762 \\
Energy & Exports & 5.963 & 2 & 0.040 & 0.8209 & 2 & 0.663 & 1.262 & 2 & 0.532 \\
Energy & All & 11.77 & 4 & 0.019 & 1.031 & 4 & 0.905 & 2.233 & 4 & 0.693 \\
\hline Exports & CO2 & 2.192 & 2 & 0.334 & 5.941 & 2 & 0.054 & 6.433 & 2 & 0.040 \\
Exports & Energy & 3.681 & 2 & 0.159 & 1.084 & 2 & 0.582 & 12.004 & 2 & 0.002 \\
Exports & All & 3.719 & 4 & 0.445 & 5.976 & 4 & 0.201 & 13.619 & 4 & 0.009 \\
\hline
\end{tabular}

Note: Coefficients are reported with probabilities in brackets. $* * *, * *$, and $*$ indicate significance at $1 \%, 5 \%$ and $10 \%$ levels, respectively. $\Delta$ defines the first difference.

\section{Conclusion}

This paper aimed to analyze the relationship between $\mathrm{CO} 2$ emission, energy consumption and exports in China, Brazil and India, while using ARDL bound testing approach and providing the evidence of the direction of causality among the variables by using Granger Causality analysis. The variables for this study have been taken from World Development Indicators (WDI), from the available period of 1978-2014. By considering three important countries of BRICS, it is important to make comparison of three economies to understand the dynamics of $\mathrm{CO} 2$ emissions.

The results show that China has a significant short run relationship between energy and export, leading to $\mathrm{CO} 2$ emissions. The implications might be the importance of energy sector in China and the necessity to implement 
of non-convertible energy in export sector for reduction in $\mathrm{CO} 2$ emissions. As for India, there is no significant relationship between the variables and $\mathrm{CO} 2$ emissions. Only a short run relationship between energy consumption and $\mathrm{CO} 2$. It is essential to consider other factors that are responsible for $\mathrm{CO} 2$ emissions in the country. In Brazil, the results show a short run relationship between $\mathrm{CO} 2$ emission and energy consumption, perhaps suggesting and inefficient use of energy. Exports has established a short as well as long run negative relationship with $\mathrm{CO} 2$, suggesting that much of the export oriented industries in Brazil have been diverted to convertible or renewable energy sources. Also, the deindustrialization effect should be considered, for limiting the exports.

\section{References}

1.Amri, F (2019). Renewable and non-renewable categories of energy consumption and trade: Do the development degree and the industrialization degree matter? Energy 173 (2019) 374 - 383.

2. Chen et al. (2016). Modeling the global relationships among economic growth, energy consumption and $\mathrm{CO} 2$ emissions. Renewable and Sustainable Energy Reviews 65 (2016) 420-431.

3. Danish et al. (2018). Energy production, economic growth and CO2 emission: evidence from Pakistan. Nat Hazards (2018) 90:27-50 https://doi.org/10.1007/s11069-017-3031-z .

4. Dinç D. and Gokmen A. (2019). Export-led economic growth and the case of Brazil: An empirical research. Journal of Transnational Management, 24:2, 122-14

5. EIA (2016). Energy Information Administration. Retrieved from URL: https://www.eia.gov/beta/international/analysis.php?iso=IND

6. Enerdata. (2014), World Energy Consumption: China and BRICS Slow, While the USA Restarts. Available: https://www.enerdata. net/publications/executive-briefing/world-energy-consumption-china-andBRICSslow-while-usa-restart.html

7. Engle, R. F., and Granger, C. W. J. (1987). Co-integration and error correction: Representation, estimation, and testing. Econometrica; 55: 251-276

8. EPA (2018). U.S. Environmental Protection Agency. Retrieved from URL: https://www.epa.gov/ghgemissions/sources-greenhouse-gas-emissions

9. Eren, B. et al (2019). The impact of financial development and economic growth on renewable energy consumption: Empirical analysis of India. Science of the Total Environment 663 (2019) 189-197.

10. IEA (2018a). International Energy Agency. Retrieved from URL: https:/www.iea.org/newsroom/news/2019/march/global-energy-demand-rose-by-23-in-2018-its-fastestpace-in-the-last-decade.html

11. IEA (2018b). International Energy Agency. Retrieved from URL: https://www.iea.org/statistics/?country=BRAZIL\&year=2016\&category=Emissions\&indicator=TotCO2\&m ode $=$ chart $\&$ dataTable $=$ INDICATORS

12. IEA (2018c). International Energy Agency. Retrieved from URL: https://www.iea.org/statistics/?country=CHINA\&year=2016\&category=Emissions\&indicator=TotCO2\&m ode $=$ chart $\&$ dataTable $=$ INDICATORS

13. IEA (2018d). International Energy Agency. Retrieved from URL: https://www.iea.org/statistics/?country=INDIA\&year=2016\&category=Emissions\&indicator=TotCO2\&mo $\mathrm{de}=$ chart $\&$ dataTable $=$ INDICATORS

14. IEA (2018e). International Energy Agency. Retrieved from URL: https://www.iea.org/statistics/?country=USA\&year=2016\&category=Emissions\&indicator=TotCO2\&mode $=$ chart\&dataTable $=$ INDICATORS

15. IEA (2018f). International Energy Agency. Retrieved from URL: https://www.iea.org/statistics/?country=EU28\&year=2016\&category=Emissions\&indicator=TotCO2\&mod $\mathrm{e}=$ chart\&dataTable $=$ INDICATORS

16. IEA (2018g). International Energy Agency. Retrieved from URL: https://www.iea.org/statistics/?country=INDIA\&year=2016\&category=Energy\%20consumption\&indicator $=$ undefined $\&$ mode $=$ chart $\&$ dataTable $=$ INDICATORS

17. IEA (2018h). International Energy Agency. Retrieved from URL: https://www.iea.org/statistics/?country=CHINA\&year=2016\&category=Energy\%20consumption\&indicator $=$ undefined $\&$ mode $=$ chart\&dataTable $=$ INDICATORS

18. IEA (2018i). International Energy Agency. Retrieved from URL: https://www.iea.org/statistics/?country=BRAZIL\&year=2016\&category=Energy\%20consumption\&indicato $\mathrm{r}=$ undefined $\&$ mode $=$ chart $\&$ dataTable $=$ INDICATORS

19. IEA (2018j). International Energy Agency. Retrieved from URL: $\mathrm{https}$ //www.iea.org/statistics/?country=EU28\&year=2016\&category=Energy\%20consumption\&indicator= undefined $\&$ mode $=$ chart\&dataTable $=$ INDICATORS

20. IEA (2018k). International Energy Agency. Retrieved from URL: 
https://www.iea.org/statistics/?country=USA\&year=2016\&category=Energy\%20consumption\&indicator=u ndefined \&mode $=$ chart $\&$ dataTable $=$ INDICATORS

21. Khobai, H (2018). Electricity Consumption and Economic Growth: A Panel Data Approach for Brazil, Russia, India, China and South Africa Countries. International Journal of Energy Economics and Policy, 2018, 8(3), 283-289.

22. Pao, $\mathrm{H}$ and $\mathrm{Fu}, \mathrm{H}$ (2013). The causal relationship between energy resources and economic growth in Brazil. Energy Policy 61 (2013) 793-801.

23. Pesaran, M. et al (2001). Bounds testing approaches to the analysis of level relationships. Journal of Applied Econometrics; May/Jun 2001; 16, 3; ProQuest pg. 289.

24. Santos, I. and Zhaohua, L. (2019). Capital Formation, Energy Consumption and Economic Growth in Brazil: An ARDL Bound Testing Approach and Granger Causality. Journal of Economics and Sustainable Development. Vol.10, No.14, 2019.

25. SEPLAN (2018). Ministry of Planning, Development and Management (2018). Macroeconomic Outlook Report. Brasilia: SEPLAN.

26. Talib, M. and Fan, H. (2019). Energy Consumption, Manufacturing Output and Economic Growth in Pakistan: An ARDL Bound Testing Approach. Journal of Economics and Sustainable Development, Vol.10, No.6, 2019.

27. Yoo, S. and Kwak, S. (2010). Electricity consumption and economic growth in seven South American countries. Energy Policy 38 (2010) 181-188. doi:10.1016/j.enpol.2009.09.003 